\title{
Helte, genier og store mænd: rapport fra en uddøende religion
}

\author{
Luther-beundring i det 19. århundrede belyst ud fra Ralph \\ Waldo Emerson \\ Lektor, dr.theol. \\ Troels Nørager, Aarhus Universitet
}

\begin{abstract}
Inspired by the $500^{\text {th }}$ anniversary of the Reformation, the present article deals with admiration of Luther in the context of $19^{\text {th }}$ century preoccupation with "genius", "heroes" and "great men". A prime example of this, combined with personal reasons for a near obsession with Luther, is Ralph Waldo Emerson (1802-82). Progressing in three steps, the first section establishes a frame of reference for understanding the religion of genius as well as hero-worship, and concludes with a brief introduction to Emerson. In the second section, the focus is on references to Luther in Emerson's sermons, in particular his critical attitude toward Luther's conception of the relation between "faith" and "works". Finally, the third section looks into Emerson's early lectures, and especially a lecture from 1835 devoted to Luther and his accomplishments as a reformer.
\end{abstract}

Key-words: genius - great men - Carlyle - Emerson - Luther.

"The religion of genius is a moribund faith: the genius is all but disenchanted".

\section{Introduktion}

Skønt vi befinder os i en tid, hvor der kan spores en voksende appetit på at dyrke historien og læse biografier, så er der ét afgørende træk, hvorved vi adskiller os fra vore forfædre: Trods populistisk længsel efter stærke ledere dyrker vi ikke helten og den store mand på samme måde som tidligere. Ifølge Darrin McMahons diagnose, som jeg her følger, har især det 20. århundredes diktatorer og det massemord,

1. Darrin M. McMahon, Divine Fury: A History of Genius (New York: Basic Books 2013), 235. 
som de forårsagede, fungeret som en effektiv advarsel mod at lade sig forføre af store mænd. Denne skepsis er måske særligt stærk i Danmark: Ikke blot har Grundtvig (som dog selv var en stor mand) mindet os om, at "ved jorden at blive det tjener os bedst"; vi er desuden det land og det folk, hvor janteloven blev opfundet og formuleret.

I det 19. århundrede var situationen helt anderledes, og det giver mening at karakterisere dyrkelsen af helten og den store mand som en form for religion. Ganske vist var tidens revolutioner og krige ledsaget af både lidelse og død, men det hindrede ikke Napoleon i at være genstand for en næsten grænseløs beundring. "Historien" blev som en selvfølge anskuet som en historie om de store mænd (og kvinder), der bestemmer dens gang. ${ }^{2}$ Mange af tidens intellektuelle reflekterede over helte og det heroiske, blandt dem USA's store, klassiske tænker, Ralph Waldo Emerson (1803-82), som jeg af to grunde har valgt at fokusere på i denne artikel: For det første optræder Luthers navn i dette forfatterskab med en overraskende hyppighed, og for det andet er Emerson ikke særlig kendt i Danmark. ${ }^{3}$ Det 19. århundredes dyrkelse af "den store mand" forekommer måske ikke specielt overraskende, set i lyset af romantik og idealisme, men som vi skal se, er der andet og mere i det - blandt andet en opfattelse af genius som guddommelig kraft og inspiration, der har rødder i antikkens filosofi og levnedsbeskrivelser.

Dette års Luther-jubilæum forekommer at være en passende anledning til at reflektere over, hvad vi eventuelt har mistet, når vi måske kun halvhjertet kan hengive os til fejringen af en stor mand som Luther. Artiklen falder i tre dele: I det første afsnit skal der etableres en forståelsesramme og gives eksempler på dyrkelsen af helten og "det geniale" i det 19. århundrede. De to følgende afsnit belyser sider af Emersons tænkning gennem et fokus på hans brug (snarere end dyrkelse) af Luther; som vi vil få at se, handler det i høj grad om spejling og identifikation hos en tænker, der selv er bevidst om at være ude i et reformatorisk ærinde.

2. Grundtvigs "verdenskrøniker" er et godt eksempel herpå. Grundtvig var selv dybt fascineret af Napoleon; i den første verdenskrønike fra 1812 kaldes han for "Guds vidunderlige Redskab" (jf. Hegels tale om Napoleon som "Verdensånden til hest"). Få år senere, i den lille bog Europa, Frankrig og Napoleon (1815), er tonen dog anderledes.

3. Dette forhold har jeg søgt at råde bod på med min bog Emerson - religion som moralsk livsform (København: Eksistensen 2017). Emerson, en hovedskikkelse i den idéhistoriske strømning kaldet New England Transcendentalism, begyndte sin karriere som unitarisk præst, men tilbragte det meste af sit liv som forfatter og foredragsholder med base i den lille by Concord nær Boston. Blandt hans vigtigste udgivelser er bøgerne Nature (1836), Essays First Series (1841), Essays Second Series (1844) og Representative Men (1850). 
1. Om helte, genier og store mænd i det 19. århundrede

Darrin McMahons Divine Fury: A History of Genius fra 2013 er religionsfilosofisk interessant ved sin idéhistoriske oversigt over, hvordan dyrkelsen af genius har udviklet sig fra antikken til i dag. Genius var i romersk religion en individuel skytsånd med en forløber i Sokrates' daimon. Den kristne kirke kunne indoptage elementer af denne arv fra antikken i den rolle, som engle og skytshelgener spillede gennem århundreder. Når geni-æstetikken i det 18. og 19. århundrede overfører mange af disse funktioner på "den store mand" og derved etablerer den moderne geni-religion, så er det naturligvis udtryk for et stykke sekularisering eller affortryllelse: "In assuming his modern form, the genius assumed powers that had once been reserved exclusively for God" (McMahon 2013, xviii). Det er ikke helt enkelt at indkredse den oprindelige, antikke opfattelse af genius, men det følgende citat giver et indtryk af fænomenets spændvidde:

[W] hether conceived as a single or double agent, a procreative urge or the highest faculty of the soul, a guardian spirit, an emissary of evil, or a fragment of the great World Soul, the governing spirit that some said permeated the universe, the classical genius, was, in all its forms, a piece of the divine in man - with him, in him, about him, animating his existence, enchanting his world (McMahon 2013, 25).

Som antydet er det altså ikke noget tilfælde, at geni-dyrkelsen i moderniteten intensiveres og antager skikkelse af en art erstatningsreligion - specielt i det 19. århundrede, der af A. N. Wilson rammende er blevet karakteriseret som perioden, hvor mange kunstnere og intellektuelle lagde Gud i graven. ${ }^{4}$ Sekulariseringen, eller Guds "trækken sig tilbage", skabte behovet for en forvisning om, at "a privileged few could see where the many were blind. Revealing, disclosing, guiding, creating, the genius enchanted a world threatened by disenchantment" (McMahon 2013, 74).

Denne i en vis forstand paradoksale dobbelthed ser man måske ingen steder tydeligere end hos den britiske historiker Thomas Carlyle (1795-1881), ${ }^{5}$ Emersons ven, med hvem han over en periode på ca. 30 år udvekslede breve, der senere er blevet udgivet $\mathrm{i}$ to bind. Som mange andre i Victoria-tidens England var Carlyle fanget i et dilemma: For hans fornuft havde kristendommen mistet sin troværdighed,

4. A. N. Wilson, God's Funeral: A Biography of Faith and Doubt in Western Civilization (New York: Ballantine Books 1999).

5. Carlyle figurerer da også som et af eksemplerne i Wilsons bog. 
men i sit hjerte følte han behovet for at tro på noget. Wilson giver os et præcist indblik i Carlyles prekære situation:

We, perhaps, approach him as a highly eccentric historian; it would be better to think of him as a journalist of genius, peculiarly in touch with the Zeitgeist which he so abominated and deplored. He was indeed an embodiment of the Victorian dilemma about God. He wished to believe - in a Supreme Lawgiver, in Duty and Morality, in a personal Guide to life. But he had looked into Christianity and found it to be false. His heart could not subscribe to it. The God and the religion of Revelation being incredible to him, Carlyle could not rest in mere unbelief. Such a thing was horrifying to him. So he spoke and wrote as if God was true, manifesting Himself less in the miraculous and unbelievable tales of religious mythology than in the inexorable workings of History itself (Wilson 1999, 56).

Det er som led i en bearbejdelse af dette traume, at Carlyle i 1840 holder seks forelæsninger om helte og heltedyrkelse. Allerede i den første af disse, omhandlende nordisk mytologi, bliver vi i indledningen mindet om Grundtvig og hans "Verdenskrøniker", når Carlyle slår fast, at "Universal History, the history of what man has accomplished in this world, is at bottom the History of the Great Men who have worked here". ${ }^{6}$ Men hvad har det med religion at gøre? Det bliver klart i det følgende citat, hvor Carlyle forklarer sine tilhørere, hvad han forstår ved "religion":

It is well said, in every sense, that a man's religion is the chief fact with regard to him. A man's or a nation of men's. By religion I do not mean here the church-creed which he professes, the articles of faith which he will sign and, in words or otherwise, assert; ... This is not what I call religion, this profession and assertion ... But the thing a man does practically believe ...; the thing a man does practically lay to heart, and know for certain, concerning his vital relations to this mysterious Universe, and his duty and destiny there, that is in all cases the primary thing for him, and creatively determines all the rest. That is his religion; or, it may be, his mere skepticism and no-religion: the manner it is in which he feels himself to be spiritually related to the Unseen World or No-World (Carlyle 1897, 8 f.).

6. Thomas Carlyle, On Heroes, Hero-Worship, and the heroic in history (Chicago: A.

C. McClurg and Company 1897), 7. 
I sin kerne er denne opfattelse af religion (som vi vil se, at også Emerson deler) ikke langt fra Luthers katekismus-definition af Gud eller afgud som "det, dit hjerte hænger ved", og alligevel er en bestemt forskel afgørende: Moderniteten viser sit ansigt i talen om skepticisme og muligheden af ikke at have nogen religion.

Luther selv dukker op i den fjerde forelæsning ("The Hero as Priest") i selskab med den skotske reformator John Knox - Carlyle var selv skotte, så valget er næppe tilfældigt. Carlyles indfaldsvinkel har sit centrum i tanken om profeten som den, der befrier sit folk fra tilbedelsen af falske idoler og afguder; Luther er derfor en profet på samme måde som Muhammed (som Carlyle vier en af sine forelæsninger til) var det: "I find Luther to have been a Breaker of Idols, no less than any other Prophet. The wooden gods of the Koreish, made of timber and bees-wax, were not more hateful to Mahomet than Tetzel's Pardons of Sin, made of sheepskin and ink, were to Luther" (ibid., 144 f.). Carlyle genfortæller Luthers livshistorie og priser hans indsats, der kulminerer i hans optræden på rigsdagen i Worms 1521, som - og nu vokser begejstringen - "may be considered as the greatest scene in Modern European History; the point, indeed, from which the whole subsequent history of civilization takes its rise" (ibid., 157 f.). Men hvis profeten har denne katharsis-agtige funktion, hvorfor så fastholde tanken om "Hero-worship" som en konstant i historien? Her nærmer vi os den mere dystre side af Carlyles civilisationskritik, nemlig hans opfattelse af, at menneskeheden "having discarded belief in the unseen God of Israel, would always look towards an Übermensch or Superman as its God-substitute" - og med tanke på det 20. århundredes barbari kan Wilson $(1999,59)$ derfor også konkludere, at "Carlyle is a prophet without honour because his prophecies were disgracefully true."

Når vi fra Carlyle bevæger os til Emerson, er der både forskelle og ligheder. ${ }^{7}$ Emersons religiøse situation er en anden: Han har ikke mistet troen, men ønsker sig en anden tro. Han beundrer sine forfædres strenge calvinisme, men indser, at den ikke lader sig bringe ind $\mathrm{i}$ moderniteten. Derfor kaster han sig ud i et reformatorisk projekt, hvis indhold er en radikal protestantisme, hvor den enkelte skal kunne se Gud "face to face" som det hedder i gennembrudsværket Nature (1836) - eller "without mediator or veil" som det udtrykkes to år senere i den med rette berømte Divinity School Address, der markerer et højdepunkt i Emersons reformatoriske bestræbelse på at komme fri af kirkelig såvel som teologisk tradition. ${ }^{8}$

7. For en nærmere placering af Emerson i sin samtid se Nørager (2017), kap. 1.

8. For mere om disse to tekster se Nørager (2017), kap. 4 og 6. Emerson-forskeren Joel Porte har rammende karakteriseret kernen i denne bestræbelse som tanken om 
Dette træk har i udpræget grad at gøre med genius - et af de hyppigst forekommende begreber i Emersons forfatterskab. Betydningen spænder vidt og er ikke så ligetil at præcisere, men to idéhistoriske formationer spiller en afgørende rolle: For det første arven fra antikken, især platonisme og nyplatonisme samt dydsetik og kravet om at danne sin "karakter" - noget som i New Englands unitarisme blev til et fokus på self-culture. Emerson er stolt over at kalde sig platoniker og filosofisk idealist, og det ser ud til, at han har bevaret elementer af den klassiske opfattelse af genius som en art personlig skytsånd. For det andet samtidens romantik, der tilføjer ideen om genius som digterens inspiration og skabende kraft. Goethe repræsenterede idealet om det alsidigt dannede menneske, og Emersons selvforståelse og identitet spænder da også over rollerne som "scholar", "poet", "preacher", "philosopher" og naturforsker eller "lover of nature".

I essayet "The Over-Soul" er Emerson inde på, at de personer, som gennem historien virkelig har virket inspirerende, er dem, der har talt indefra, og har kunnet gøre det, fordi de talte ud af enheden eller den ubrudte kommunikation mellem "oversjelen" (den universelle bevidsthed) og deres egen sjæl. Derpå fortsætter han med en formulering, der er egnet til at kaste yderligere lys over, hvad han forstår ved "genius":

The same Omniscience flows into the intellect, and makes what we call genius. Much of the wisdom of the world is not wisdom ... Among the multitude of scholars and authors, we feel no hallowing presence; ... But genius is religious. It is a larger imbibing of the common heart (CW 2, 170).

Genius er, kunne vi sige, et stykke af det guddommelige, der pludselig viser sig i mennesket, og derfor er det heller ikke noget tilfælde, at Emerson har en forkærlighed for at tale om Gud som "the God within".

Et sidste skridt er nødvendigt, førend vi kan fokusere på Emersons omtale og brug af Luther; vi må - i delvis forlængelse af Carlyle - sige lidt om, hvordan han opfatter helte og store mænd. "Heroisme" er emnet for en af Emersons tidligste forelæsninger, og manuskriptet

at "Ought and Beauty, Duty and Joy, Science and Ecstasy, Divinity and the World, must merge in the new hypostatic unity of a living religion of the soul." Citeret fra Joel Porte, Representative Man: Ralph Waldo Emerson in His Time (New York: Oxford University Press 1979), 120.

9. Jf. Troels Nørager, “'The God Within' and Religious Self-Reliance”, "What is Human?" Theological Encounters with Anthropology, red. Eve-Marie Becker m.fl. (Göttingen: Vandenhoeck \& Ruprecht 2017), 235-256. 
blev nogle år senere til essayet af samme navn i bogen Essays First Series (1841), der for alvor slog hans navn fast. Indledningsvis henvises til Carlyle "with his natural taste for what is manly and daring in character", ${ }^{10}$ men ellers er det Plutarchs Vitae, hans skildringer af berømte mænd, der tilkendes en hovedrolle. Emerson, der allerede i barndommen kom til at elske dette værk, skriver i denne forbindelse, at "if we explore the literature of Heroism, we shall quickly come to Plutarch, who is its Doctor and historian ... Each of his "Lives" is a refutation to the despondency and cowardice of our religious and political theorists" (ibid.). Men hvad forstår Emerson ved heroisme? Det er, hedder det, "obedience to a secret impulse of an individual's character" (ibid., 374) - eller udtrykt helt kort: "Self-trust is the essence of heroism" (375). Denne opfattelse af heroisme bidrager derfor også til betydningen af Emersons måske mest berømte begreb, nemlig self-reliance. ${ }^{11}$

I forhold til vores umiddelbare forståelse af helte som unikke personer, man kun sjældent støder på, virker det overraskende, når Emerson betoner, at "[a]ll these great and transcendent properties are ours" (377). Forklaringen er, at han ser hvert menneske som et mikrokosmos, der participerer i en verdenssjæl eller i det, han kalder for "Universal Mind" (Gud). Ret beset er helten eller den store mand derfor kun representativ for et potentiale, som via genius kan vækkes til live i ethvert menneske. Dermed har vi samtidig etableret forbindelsen til Emersons berømte værk fra 1850, Representative Men, hvor Platon repræsenterer "tænkeren”, Shakespeare "digteren”, Napoleon "verdensmanden", Montaigne "skeptikeren" og Swedenborg "mystikeren."12 Til forskel fra Carlyles værk om de store mænd har Luther altså ikke fået en plads i denne sammenhæng; men i lighed med Carlyle fremhæver også Emerson forbindelsen mellem helte/religionsstiftere og det, vi tilbeder i religionen: "Our religion is the love and cherishing

10. Ralph Waldo Emerson, Essays \& Lectures (New York: The Library of America 1983), 373.

11. Se til dette (desværre ofte misforståede) begreb Nørager (2017), 144-154. Om Luther siger Emerson i en forelæsning, at "No man in history ever assumed a more commanding attitude or expressed a more perfect self-reliance". Citeret fra S. E. Whicher og R. E. Spiller (udg.), The Early Lectures of Ralph Waldo Emerson Vol. I (Cambridge, MA: Harvard University Press 1959), 136 (herefter: EL 1).

12. Om deres samlede betydning skriver Emerson (Essays \& Lectures, $630 \mathrm{f}$.): "One gracious fact emerges from these studies, - that there is true ascension in our love ... The study of many individuals leads us to an elemental region wherein the individual is lost, or wherein all touch by their summits. Thought and feeling, that break out there, cannot be impounded by any fence of personality. This is the key to the power of the greatest men, - their spirit diffuses itself". 
of these patrons. The gods of fable are the shining moments of great men" (ibid., 615 f.).

Men hvad kan eller bør man bruge de store mænd til? Det spørgsmål behandles i bogens indledende forelæsning under overskriften "Uses of Great Men". Det korte svar er, at de minder os om vore egne, iboende muligheder samtidig med, at de indirekte opfordrer os til at "gå selv" - og undgå enhver konformitet og imitation af andre. Netop risikoen for følgagtighed og efterligning synes at være grunden til, at Emerson gør os opmærksom på, at "a new danger appears in the excess of influence of the great man. His attractions warp us from our place. We have become underlings and intellectual suicides" - hvorefter følger den humoristiske pointe: "Every hero becomes a bore at last" (627). Emerson er ofte - og ikke uden en vis ret - blevet kritiseret for at tænke alt for individualistisk. Jævnført med Carlyles hero-dyrkelse bør man dog ikke overse den væsentlige forskel, at Emersons idé om de store mænds repræsentativitet samtidig er udtryk for en demokratisering, som er en del af den nye, selvstændige nations "American spirit."13

\section{Luther i Emersons prædikener}

Skønt Luthers betydning for Emerson er bemærkelsesværdig, leder man i forskningen stort set forgæves efter en behandling af emnet. En markant undtagelse udgør dog den amerikanske litteraturprofessor Joel Porte, som med rette har hæftet sig ved, i hvor høj grad den helt unge Emersons dagbogsoptegnelser udviser en vekslen mellem på den ene side ambitionen om at blive en stor mand i pagt med "the American spirit" og på den anden side fortvivlelse over - eller manglende tillid til - egne evner. Inspireret af psykoanalytikeren Erik H. Eriksons klassiske studie Young Man Luther fra 1958 ser Porte i denne indre splittelse og søgen efter en afklaret identitet en parallel mellem Luther og Emerson, og skriver:

I introduce Luther, or rather Erikson's Luther, here not simply because the parallels between his own vocational, and psychic, crises in early manhood and Emerson's are striking, but also because Emerson himself exhibits, especially in the 1830 's, what might be called a minor obses-

13. Om Emersons politiske filosofi se bl.a. Daniel S. Malachuk, "The Republican Philosophy of Emerson's Early Lectures", The New England Quarterly 71 (1998), 404-428. 
sion with Luther, culminating in his 1835 lecture on the great dissenter (Porte 1979, 290).

Forelæsningen om Luther venter vi med til næste afsnit; på dette sted drejer det sig om den Emerson, der mente at kunne indfri sine store ambitioner ved at satse på veltalenhed (eloquence) og derfor valgte at blive præst for Bostons unitariske Second Church. ${ }^{14}$ Hans i alt knap to hundrede prædikener er i vor tid blevet udgivet i fire bind, hvor Luthers navn dukker op i alt tolv gange, for det meste som led $\mathrm{i}$ en opremsning af store, religiøse personligheder. ${ }^{15}$ To af disse referencer til Luther er der dog grund til at se lidt nærmere på.

Den første er en prædiken fra 1829 over Jak 3, 17 ("The wisdom which is from above, is gentle"), hvor Emerson generelt priser mildhed som en kristen dyd, men samtidig fremhæver apostlen Peter og reformatoren Luther som eksempler på, at der også er undtagelser fra reglen. Om Luther hedder det således:

\begin{abstract}
And Luther, who overthrew the power of the church which abused the prophecy to Peter, and confronted for truth's and conscience's sake, all the wrath of the civil and ecclesiastical arm that had crushed the elder reformers, - was not gentle. Yet no one can deny the sublime merit to both of these moral heroes. ${ }^{16}$
\end{abstract}

14. Netop veltalenhed er imidlertid et punkt, hvor Emerson direkte identificerer sig med Luther; i forelæsningen "Society" hedder det således med implicit tilslutning: "Luther says earnestly - 'Whoso can speak well, the same is a man.". Citeret fra S. E. Whicher, R. E. Spiller \& W. E. Williams (eds.), The Early Lectures of Ralph Waldo Emerson, Vol. II, 1836-1838 (Cambridge: The Belknap Press of Harvard University Press 1964), herefter: EL 2.

15. Én af disse opremsninger, fra ca. et halvt år før Emerson i 1832 opgav sit embede, er dog af særlig interesse, fordi Emerson her antyder den konfessions- og dogmeløse kristendomsopfattelse, som er karakteristisk for ham. Det afgørende, siger han her, er kristendommen som moralsk sandhed og "Gud" som forvisningen om, at verden er styret af en moralsk lovmæssighed. Men, spørger han nu, "does it take one charm from the lowly grace of Christ? does it take away any authority from his lips? It abridges what belongs to persons, to places, and to times but it does not touch moral truth. We are assured in any speculation we may indulge concerning the tenants of other regions in the wide commonwealth of God, that if we could carry the New Testament to the inhabitants of other worlds we might need to leave Jewish Christianity and Roman Christianity, Paul and Apollos and Cephas and Luther and Socinus, but the moral law, justice and mercy would be at home in every climate and world where life is". Citeret fra Wesley T. Mott, The Complete Sermons of Ralph Waldo Emerson, Vol. 4 (Columbia and London: University of Missouri Press 1992), $158 \mathrm{f}$.

16. Albert J. von Frank (udg.), The Complete Sermons of Ralph Waldo Emerson, Vol. 1 (Columbia: University of Missouri Press 1989), 261. 
Det er altså Luthers kamp for sandhed op imod enhver autoritet, der fremhæves af Emerson, samt det at Luther så frygtløst adlød samvittighedens røst. Intetsteds kommer dette sidste tydeligere til udtryk end i samme Luthers optræden på rigsdagen i Worms, og lidt senere i samme prædiken henvender Emerson sig da også direkte til sin menighed med disse ord:

\begin{abstract}
You all know the famous sentence uttered by Luther when his friends endeavoured to dissuade him from going to the Diet of the States, at Worms, when summoned thither on the charge of heresy, by representing the manifest danger of his life. He replied in language so harsh as could not be repeated, but for the heroism of the sentiment: "I will go to Worms, though there be as many devils on the road, as there be tiles on the houses of that city" (ibid., 262).
\end{abstract}

En anden omtale af Luther fra samme år skiller sig ud ved netop ikke at være en identificerende brug af Luther, men derimod en stillingtagen til Luthers teologiske anliggende. Konteksten er en prædiken over Matt 7, 16 ("Ye shall know them by their fruits"), og temaet er reformatorisk centralt: forholdet mellem tro og gerninger. ${ }^{17}$ Emerson beskriver, hvordan dette spørgsmål siden reformationen har udgjort en gennemgående kontrovers, hvor den ene part har urgeret kristendommen som "a system of belief", mens den anden part betoner, at den er "a practical system." Emerson finder begge positioner énsidige og understreger vigtigheden af at holde tro og gerninger sammen: "I believe that these principles cannot be divorced. Either is imperfect without the other". ${ }^{18}$ Og det samme mente jo den Luther, som hævder, at de gode gerninger flyder ud af troen og at "god mand gør gode gerninger".

Alligevel mener Emerson, at gerninger og praksis trods alt er et mere sikkert tegn end "troen alene", og tilslutter sig dermed Matt 7, 16: "By their fruits, by their fruits, said the Saviour, ye shall know them" (ibid., 48). Det er blandt andet i lyset heraf, at Emerson, interessant nok, udlægger Luthers position som implicerende en modsatning mellem tro og gerninger. Vel åbner han for muligheden af,

17. I forelæsningen om Luther gør Emerson efter at have omtalt retfærdiggørelsen "of grace by faith" som "the seed of the Reformation" netop forholdet mellem tro og gerninger til Luthers centrale anliggende: "This doctrine was henceforward his main theme: Works and Faith, or, what was to him synonymous, the Law and the Gospel” (EL 2, 121).

18. Citeret fra Teresa Toulouse and Andrew Delbanco (eds.), The Complete Sermons of Ralph Waldo Emerson, Vol. 2 (Columbia and London: University of Missouri Press 1990), 47. 
at denne radikalitet kan tilskrives datidens heftige stridigheder, men Luthers urgering af "troen alene" udgør - som det fremgår af en længere passage i prædikenen - ikke desto mindre for Emerson at se en teologisk afsporing, som der bør gøres op med:

No pretension can be more destitute of colour than the setting up faith as a principle of the heart in opposition to good works. It has no claim in reason or in any true interpretation of Scripture, to such distinction. But every body knows the extremes of absurdity to which the heat of party will push even intelligent and well disposed men, and therefore there is nothing surprising in the history of opinions upon this point. There was long a persuasion that there was a virtue in believing a great deal and this doctrine gained such ground that at the Reformation it kept its footing when the other Dagons in the temple of Error were shaken down. Luther even took great offence at the eloquence and plainness with which St. James in his Catholic epistle sets forth the worth of good works and called it "an Epistle of Straw" and himself maintained with tenacity that good works were not essential to salvation. One of his followers, Amsdorff, went one step farther and taught that good works were an impediment to salvation. These extravagances need no comment. He that has grown up in the belief that the worship of God consists in an acceptance of articles of belief, or in any temporary state of the mind, may grow used and so, insensible to these absurdities; but to a mind once liberated from them, no faith, no feelings in the least degree hostile to good works or that speaks of any merit independent of them, will find any respect ... All the theology in the world that disparages good works must melt away, - as smoke before their everlasting beauty (ibid.). ${ }^{19}$

Trods indre splittelse og usikkerhed lykkedes det Emerson at komme frelst igennem karriereskiftet fra præst til foredragsholder, ${ }^{20}$ men

19. Man må dog ikke tro, at Emerson generelt tager afstand fra Luthers værker; tværtimod viser den følgende dagbogsoptegnelse, at han har set en mulighed for at "oversætte" indholdet og derved bringe det i overensstemmelse med sit eget anliggende: "Do you imagine that because I do not say Luther's creed all his works are an offence to me? Far otherwise. I can animate them all that they shall live to me. I can worship in that temple as well as in any other. I have only to translate a few of the leading phrases into their equivalent verities, to adjust his almanack to my meridian $\&$ all the conclusions, all the predictions shall be strictly true" (citeret fra Porte (1979), 290).

20. I øvrigt fortsatte han i flere år med lejlighedsvis at prædike, og han betragtede selv de folkeoplysende foredrag som en alternativ form for prædikestol. Se hertil fx: A. M. Baumgartner, “'The Lyceum is My Pulpit': Homiletics in Emerson's Early Lectures," American Literature 34 (1963), 477-486. 
hjælpen kom i høj grad netop fra en udstrakt identifikation med Luther, for "Emerson's difficult transition from self-divided minister to self-affirming lecturer and author bears a striking analogy to Erik Erikson's portrayal of the difference between Martin the monk and Luther the preacher" (Porte (1979), 296).

\section{Luther i Emersons tidlige forelæsninger}

Som allerede antydet optræder Luthers navn med en overraskende hyppighed i Emersons tidlige forelæsninger fra årene 1833-37. Jeg er enig med Joel Porte i, at dette forhold skal tages som udtryk for, at Emerson i denne karrieremæssigt usikre periode oplevede et behov for identificerende at kunne spejle sig i Luther. Referencerne til Luther er for mange til, at de alle kan behandles i denne artikel; jeg tager afsæt i selve forelæsningen om Luther, hvorefter vi skal se eksempler på den videre brug, som Emerson gør af Luther.

Det er desværre ikke muligt at fastslå omfanget af Emersons kendskab til Luthers skrifter; selve Luther-forelæsningen henviser flere gange til den engelske oversættelse af Tischreden (Luthers bordtaler), og udgiverne bidrager med den realkommentar, at Emerson herudover har baseret sin fremstilling på to samtidige Luther-biografier samt på Luthers store kommentar til Galaterbrevet fra 1531/35. ${ }^{21} \mathrm{Al}-$ lerede fra forelæsningens begyndelse betoner Emerson for sine tilhørere Luthers helt særlige betydning med disse ord: "Martin Luther the Reformer is one of the most extraordinary persons in history and has left a deeper impression of his presence in the modern world than any other except Columbus" (EL 1, 119). Senere uddyber han denne helt særlige status: "Luther's singular position in history is that of a scholar or spiritual man leading a great revolution, and from first to last faithful to his position" (127). Hverken her eller i det følgende er ordvalget tilfældigt, men indikerer både spejling og identifikation: Emerson er selv en "scholar" og "spiritual man", og når han eksempelvis fremhæver Luthers "sublime reliance on the simple force of truth" (130), så kunne han ligeså vel have talt om sig selv.

21. De to biografier skulle angiveligt være: Alexander Bower: The Life of Luther (London 1813) og John Scott: Luther and the Lutheran Reformation (New York 1833). Luthers kommentar til Galaterbrevet omtales i forelæsningen med disse ord: "His Commentary on Galatians is evidently writ under the impression that there was a strict parallelism between the historical position of St. Paul and his own, and he uses the Epistle to defend and explain his own acts" (EL 1, 136). 
Som allerede antydet kan Emersons forestillinger om "den store mand" spores helt tilbage til antikken; dydsetik, aristokratiske værdier (senere genoplivet hos forbilledet Montaigne) og det at danne sin karakter spiller en central rolle. Alt dette ser han inkarneret i Luther og i høj grad værd at efterligne, og derfor angiver han også forelæsningens formål som "to form and exhibit a clear conception of the peculiar genius of the man" (119). I idealet indgår også det at besidde en stærk vilje, og netop dette er ifølge Emerson karakteristisk for Luther: "Never, it would seem, did the human Will clothe itself in more fit expression than in this man's words. It seemed as if in him dwelt a spirit of the most terrible determination that ever lived in a human breast" (124). Denne "terrible determination" manifesterede sig blandt andet i Luthers berygtede opfordring til at slå de oprørske bønder ned - en episode i reformationen, som siden har været årsag til, at mange har taget afstand fra Luther. ${ }^{22}$ Også Emerson berører kort dette tema, men det bemærkelsesværdige er, at han ikke vakler i sin beundring af den store reformator: "The rapid progress of the Reform broke out into rebellion, and the "Peasants' War". Luther's behavior was irreproachable" (126). Altså: ingen grund til at bebrejde Luther noget! Begrundelsen er, at Emerson finder Luthers holdning i denne sag afbalanceret: På den ene side irettesætter han oprørerne, og på den anden side opfordrer han fyrsterne til "moderation, affirming to them in language hitherto unheard, the rights of the people" (127). I et jubilæumsår som 2017 må dette vel karakteriseres som en velkommen hilsen og støtte til Luther fra New England. ${ }^{23}$

Der er dog også områder, hvor Emerson - trods sin generelt store beundring - finder mangler og svagheder hos Luther. Et af disse er filosofi og metafysik, et tema med aktuel interesse, fordi man ser visse bestræbelser på at rehabilitere Luther som filosof. Som det følgende

22. Karakteristisk for dette moderne ubehag over for Luthers holdning i Bondekrigen er følgende udtalelser i Heinz Schillings store Luther-biografi, Martin Luther - rebel i en opbrudstid (København: Kristeligt Dagblads Forlag 2014, 290): "Luther så Djævelen på spil - til skade for evangeliet, men også til evig fortabelse for enhver, der lod sig friste af ham. Kun sådan kan vi forstå den i dag kynisk forekommende opfordring til herrerne om at forbarme sig over bønderne ved at støde og hugge dem ned". Og et par sider senere: "Selvom reformatoren som sædvanlig vurderer tingene i det for ham så ufravigelige evangeliske perspektiv, har hans ubønhørlige holdning et skær af ligefrem fundamentalistisk fanatisme" (ibid., 294).

23. Det hører dog med til historien, at også Emerson har blik for, at Luthers stærke vilje kunne slå om i fanatisme: "There is in Luther's character a very important element which qualified and ennobled this Enthusiasm. A man of his mighty heart and excessive Imagination is in danger of insanity, and, in such circumstances as he fell upon, of a Mohammedan fanaticism ... The healing principle, the balancewheel that kept these dangerous powers from extravagant motions was his warm social affections. His heart was in the right place" (138). 
citat viser, mener Emerson dog ikke, at det er her, Luther har sin force:

He was not a philosopher; his speculations upon abstract questions are of no worth; Aristotle's logic had helped his dialectic, but not extended his views; he had no fitness to receive scientific truths, and he makes himself very merry with the recent astronomical discoveries, which he calls "starpeeping", and confounds ignorantly with astrology. Nay his theology is Jewish: His reform is directed at the corruptions of the Roman Church, not at its ancient creed, and if he can attain the Christianity of the first ages, he is quite content (131).

Men hvorfor kalder Emerson Luthers teologi for "jødisk”? Ville Luther ikke netop gøre op med lovens tyranni? To forhold synes at spille ind: Dels Luthers fokus på loven, dels at Emerson ser Luther som en pendant til de gammeltestamentlige profeter:

Even the ethical law which he saw so clearly, and which set him upon his attack on Indulgences, he did not state as a philosophical truth, but only as a Scripture doctrine on the article of Justification. In his controversy with Zuinglius he was wholly in the wrong. He was not more a general scholar and not more a philosopher than was Isaiah or Ezekiel among the ancient Hebrews. He was like them the Prophet, the Poet of his times and country (131 f.).

Det er altså i høj grad fraværet af filosofisk refleksion, som betinger Emersons afstandtagen fra Luther. Emersons egen opfattelse af tilværelsens karakter af moralsk lovmæssighed var blandt andet influeret af Kant, og for ham selv blev idealismens sondring mellem forstand ("understanding") og fornuft ("reason") noget af en åbenbaring og ledte ham til et gudsbegreb, hvor Gud er den universelle fornuft eller "Universal Mind." ${ }^{24}$ Den Luther, der satte troen op imod "die Hure Vernunft", kan Emerson altså ikke bruge til noget. Det interessante er imidlertid at se, hvilke konsekvenser dette får for opfattelsen af Gud. I forelæsningen står dette tema centralt, og Emerson indleder med følgende karakteristik af Luthers gudsbegreb:

In his religious faith, there is no approach to the conception of God as the Pure Reason, which is the faith dear to philosophic minds, but he

24. For en uddybning af disse spørgsmål se Nørager (2017) kap. 4 og 5. Emerson overtog denne distinktion fra Coleridge og tilføjede dermed (i forhold til Kant) fornuftsbegrebet en romantisk-intuitiv dimension: fornuften er det organ, hvormed vi erkender højere sandheder og åndelige ting. 
adhered to the lowest form of the popular theology, - I had almost said, - mythology. His view of the Deity is so extraordinary that no understanding of his character can be obtained without it (134).

Bemærk tilføjelsen: Emerson er enig med Carlyle i, at et menneskes vigtigste anliggende er dets "religion," og netop derfor ligger nøglen til at trænge ind i Luthers personlighed (og det er jo, hvad Emerson har gjort til selve formålet) i hans gudsbegreb. Til belysning heraf citerer Emerson flere passager fra Luthers bordtaler, og som det følgende citat viser, har han her fået et indtryk af Luthers gudsbegreb som både arkaisk og hedensk:

\begin{abstract}
This gross and heathen theism is almost precisely that of Luther. Under this God he regarded himself a chosen instrument, and felt his commission with so much more intensity from the distinctness of which this idea of God was capable. God is in Luther's mind a Genius or local and partial tutelary Daemon, the lover of his Church, the hater of its enemy, the chiefs of which are the Pope and the Turk. He addresses the Deity therefore much as a subject who is conscious that his great services to his king and his known devotion to his service entitle to use great liberties of speech (134).
\end{abstract}

Emerson afrunder omtalen af gudsbegrebet med at sige, at "Gud" og "Djævelen" hos Luther er to sider af samme sag i den bestemte henseende, at de begge er tænkt alt for konkret: "Luther's man-like God required the same outstanding distinctness in the form of the Devil. His fidelity to this idea is as unflinching as his faith in the Confession of Augsburg" (135). Enhver luthersk teolog vil selvsagt i talen om Luthers "man-like God” kunne se en afgørende kristologisk og soteriologisk pointe, men den calvinistisk-unitariske Emerson ser det anderledes. Trods denne kritik af gudsbegrebet fastholder Emerson dog sin store beundring for Luthers person og indsats. Forelæsningens morale formulerer han på denne måde: "In the story of this singular person who was the instrument of the greatest of revolutions one moral appears, the superiority of immaterial to material power" (143). Det vil sige: Luthers person og indsats bliver et eksempel, der understøtter Emersons filosofiske idealisme og den heri indeholdte overbevisning om, at åndelige lovmæssigheder udgør den vigtigste kraft i tilværelsen.

Forelæsningen rummer desuden indslag af en for Emerson karakteristisk samtidskritik, der retter sig imod tidens overfladiskhed og konformitet: samfundet, hedder det, "has now become so imitative and artificial that he [dvs. Luther] stands in glaring contrast. Very 
hardly now could the great man be true. Appearances are always to be kept up. (...) But that was an earnest age and Luther the most earnest man" (142). Det samme tema dukker op i forelæsningen "Being and Seeming", hvor Luther (og Napoleon) fremhæves som eksempler på den store mand, der handler spontant og ubekymret i forhold til enhver forestilling om, hvad "man" gør:

So in this great society wide lying around us a critical analysis would find very few spontaneous actions. Almost all is custom or mere obedience to the senses. A new action is one which flows from character; it is a new hearkening to the divine oracle and instantly strikes us as a creation. A new action commands us and is the Napoleon or Luther of the hour (EL 2, 304).

Emerson er dog ganske nuanceret her: Han er således ikke blind for de fordele, der knytter sig til, at et givet samfunds medlemmer orienterer sig efter nogle - mere eller mindre - fælles forestillinger om decorum; hvad han vil minde os om er blot, at disse fordele betales med en høj pris: "It is a great convenience, like a good road or a steamboat. But this also has its price. The unkempt Isaiah, the tart tongue of Milton, the plain majesty of Luther, the slovenly strength and integrity of Montaigne, we shall not find" (EL 2, 162).

Jeg afrunder denne fremstilling med en sidste reference til Luther, nu fra en anden af de tidlige forelæsninger med titlen "Human Culture". Emerson begynder med at stille sig selv spørgsmålet, hvad der dybest set udgør kulturens grundlag? Han besvarer det ved at henvise til sin filosofiske idealisme, men med den vigtige pointe, at "idealisme" netop ikke, sådan som mange fejlagtigt tror, står i modsætning til "realisme", men derimod til det blot tilsyneladende virkelige ("The Actual"). Med baggrund i denne afstand mellem det, der er og det, der kunne og burde være, kritiserer Emerson i sin samtid det, han kalder for "the deadness of religion". Vi er altså endnu engang fremme ved Emersons ønske om en radikal reformation af den etablerede kristendom; og når han i det følgende citat taler om "the youthful saint", så kan han meget vel have tænkt på sig selv som den, der spejler sig i tidligere reformatorer og finder styrke $\mathrm{i}$ at identificere sig med deres mod til at træde op imod autoriteterne og det tilvante - ecclesia semper reformanda:

I answer the basis of Culture is that part of human nature which in philosophy is called the Ideal ... Ideal is not opposed to Real, but to Actual. The Ideal is the Real. The Actual is but the apparent and the Temporary ... The pious heart bewails the deadness of religion. Luther, Huss, Cob- 
ham, Knox, moved by this painful contrast of the actual with the ideal worship, shake down the churches of a thousand years; and already the youthful saint following the same eternal instinct sees the shortcomings of their reformation (EL 2, 217).

\section{Konklusion}

Inspireret af reformationsjubilæet har denne artikel rejst spørgsmålet om "den store mand" og belyst det 19. århundredes beundring for Luther med eksempler fra en ikke-luthersk kontekst: Carlyles England og Emersons New England. Det er blevet vist, hvordan den unge, usikre Emerson med store ambitioner om at reformere sin samtids "døde" religion fandt styrke i at kunne spejle sig i Luthers person og virke. Samtidig har vi set, at Emerson fandt det nødvendigt at rette en kritik mod Luther, dels hvad angår forholdet mellem tro og gerninger, dels i forhold til gudsbegrebet. Der er ingen tvivl om, at Emerson selv har opfattet denne kritik som værende i Luthers egen ånd, det vil sige som udslag af behovet for hele tiden at fortsætte og korrigere et reformatorisk anliggende.

Datidens næsten religiøse dyrkelse af genius og "den store mand" har undergået en form for sekularisering eller affortryllelse. Det kan man ikke bare se bort fra. Alligevel kan der være grund til at overveje, om vi har smidt lidt for meget barn ud med badevandet: Har Emerson ikke en pointe, når han betragter de store personligheder som representative - og netop derfor mulige at tage ved lære af og gøre til gode forbilleder? Det andet spørgsmål, som Emersons kritik af Luther giver anledning til at overveje, specielt i et jubilæumsår, er, om ikke reformationens dybeste pointe netop består $i$, at den skal fortsættes? 